\title{
Effect of COVID-19 Restrictions on Nomophobia and Smartphone Addiction Levels
}

\section{COVID-19 Pandemi Kısıtlamalarının Nomofobi ve Akıllı Telefon Bağımlılık Düzeyleri Üzerine Etkisi}

\author{
İzzet Fidancı 1(D), Hilal Aksoy 1(D), Duygu Yengil Taci 2(D), Duygu Ayhan Başer 1(D), \\ Mustafa Cankurtaran 3(D)
}

1. Hacettepe University, Faculty of Medicine, Department of Family Medicine, Ankara, Turkey

2. Ankara Education and Research Hospital, Department of Family Medicine, Ankara, Turkey

3. Hacettepe University, Faculty of Medicine, Department of Internal Medicine, Division of Geriatric Medicine, Ankara, Turkey

\section{Abstract}

Objective: The aim of this study is to investigate the effect of the restrictions imposed due to the COVID-19 Pandemic on nomophobia and smartphone addiction levels.

Method: People aged 18 and over who agreed to participate in the study and who have applied the "Nomophobia Scale" and the "Smartphone Addiction Scale" (SAS) within 1 year before the pandemic restrictions were included in the study by applying the same questionnaire during the period after the pandemic restrictions.

Results: The number of participants was 100. A statistically significant difference was found between the prepandemic and post-pandemic nomophobia scores of the participants. While the mean nomophobia score was 74.2 before the pandemic, it was 76.2 after the pandemic. There was a statistically significant difference between the smartphone addiction scale scores of the participants before and after the pandemic. While the mean SAS score before the pandemic was 34.0, it increased to 36.7 after the pandemic.

Conclusion: Behavioral changes are inevitable during the COVID-19 pandemic and the need for technology has increased. Therefore, necessary measures should be taken to prevent psychological disorders caused by the increase in technology-related addiction levels, and efforts should be made to reduce or control addiction levels.

Keywords: COVID-19, pandemic, nomophobia, smartphone addiction

Öz

Amaç: Bu çalışmanın amacı günümüzde gittikçe yaygınlaşan nomofobi ve akıllı telefon bağımlılı̆ının COVID-19 Pandemi nedeniyle uygulanmaya başlanan kısıtlamaların bu bağımlılık düzeylerine etkisinin araştııımasıdır.

Yöntem: Araştırmaya 18 yaş ve üstündeki kişilerden çalışmaya katılmayı kabul eden ve pandemi kıııtlamalarının uygulanmaya başlanmasından önceki 1 yll içinde "Nomofobi Ölçeği" ve "Akıllı Telefon Bağımlılığı Ölçeği'(ATBÖ) uygulanmış kişilere pandemi kısıtlamaları uygulanmaya başlanmasından sonraki dönemde aynı anket tekrar uygulanarak dahil edilmişlerdir.

Bulgular: Katılımcı sayısı 100 olup, \%53'ü kadın ve \%47'si erkektir. Pandemi sonrası Katılımcıların pandemi öncesi ve pandemi sonrası nomofobi puanları arasında istatistiksel olarak anlamlı bir fark vardır. Pandemi öncesi Nomobofi puan ortalaması 74.2 iken pandemi sonrası bu oran 76.2 olarak elde edilmiş̧tir. Katılımcıların pandemi öncesi ve pandemi sonrası akılı telefon bağımlıık ölçek puanları arasında istatistiksel olarak anlamlı bir fark vardır. Pandemi öncesi ATBÖ puan ortalaması 34.0 iken pandemi sonrası bu oran 36.7 olarak elde edilmiştir.

Sonuç: COVID-19 pandemi sürecinde davranış değişiklikleri meydana gelmesi kaçınılmaz olmuş olup, teknolojiye olan gereksinimde artış meydana gelmiştir. Dolayısıyla teknolojiıle ilişkili bağımılılık düzeylerindeki artışın yol açacağı psiklojik bozuklukların önüne geçmek için gerekli önlemler alınarak, bağımlılık düzeylerinin azaltılması ya da kontrol altına alınmasına çalışılmalıdır.

Anahtar kelimeler: COVID-19, pandemi, nomofobi, akıllı telefon bağımlılı̆ı 


\section{Introduction}

The term nomophobia is derived from the combination of the words NO-Mobile-PHOBIA, and as can be understood from these words, it is defined in clinical psychology as the irrational fear experienced by individuals when they cannot access their mobile device or when they are not online $(1,2)$. The risk of addiction also increases in parallel with the increase in smartphone usage areas and therefore the "substance use and addiction disorders" diagnosis category is included in the version of DSM-6 (The Diagnostic and Statistical Manual of Mental Disorders-6) (3,4). If it occurs in situations of not perceiving the events in the environment due to stress or panic situation and feeling of constantly controlling the smartphone, the patient is at the beginning of nomophobia. As the use of smartphones increases, the feeling of happiness started to be released to the brain. This is explained by mobile devices and the happiness hormone that releases dopamine. If hormones that give a feeling of happiness to the person are secreted as the notification arrives on the person's smartphone, this indicates that the addiction phase increases (5). Addictions are important in terms of being careful because having any addiction causes predisposition to other addictions (6-10). In a study conducted with 2163 participants in the UK, 53\% of smartphone users had nomophobia. It was also stated that males are more prone to nomophobia than females (7).

Due to the COVID-19 pandemic and related constraints, the use of the internet and technology has increased as a result of the provision of needs and education, and thus, its effect on addiction has been observed $(5,6)$. In the time interval in our study, our country (Turkey), various restrictions were applied. This period of the study covers the period after the first peek of the pandemic. The most common is; between 21:00 and 05:00 every day and as a curfew on weekends. Besides, restaurants and cafes can only serve takeaway. A determined number of people can be found for all public institutions. Due to the restrictions during the COVID-19 pandemic, there may be changes in the levels of nomophobia and smartphone addiction. Our study includes the sharing of our experiences to evaluate the dependence on technology during the pandemic period and to prevent psychological problems afterward. This study aims to examine the effects of restrictions imposed due to the pandemic on nomophobia and smartphone addiction levels. In periods that cause behavioral change such as a pandemic, addiction levels may increase uncontrolled due to the need for technology.

\section{Method}

\section{Sample}

This study was conducted with observational, analytical, and prospective methods between January and April 2021. The study included individuals aged 18 and over who were applied the "Nomophobia Scale" and the "Smartphone Addiction Scale" in the 1 year before the beginning of pandemic restrictions (February 2019 - February 2020) and then received the same questionnaire during the period once again when these restrictions were in effect.

\section{Procedure}

Written consent was obtained from those who accepted to participate in the study. All procedures performed in studies involving human participants were following the ethical standards of the institutional and/or national research committee (The approval was obtained from the Turkish Ministry of Health, Platform for Scientific Research (Form no: 2020-12-02T15_32_50) and Hacettepe University NonInterventional Clinical Research Ethics Committee (Decision no: 2021/01-12 and Project no: G0 20/1189) before the study.) and with the 1964 Helsinki declaration and its later amendments or comparable ethical standards. 
Questions evaluating socio-demographic information (age, gender, and university department) followed by a questionnaire consisting of "Nomophobia Scale" (20 questions) and "Smartphone Addiction Scale" (10 questions) were applied to those who accepted to participate in the study. All participants whose nomophobia and smartphone addiction levels were measured before the pandemic and who had no data deficiency were included in our study. The criteria for exclusion are only lack of data and not being reached after the pandemic. Study scales were applied to a total of 121 people before the pandemic. For this reason, power analysis has not been done. 11 of them were missing data. Since 10 participants could not be reached, they could not be included in the study. The study was conducted with 100 participants, who can be reached in 3 months between January and April 2021.

Pandemic restrictions include curfews on certain dates and for certain hours, the obligation to wear a mask, rules to comply with social distance, and isolation of those diagnosed with and/or contact with COVID-19.

\section{Measures}

\section{Nomophobia Questionnaire}

Within the scope of the study, Nomophobia Questionnaire (NMP-Q) developed by Yildirim and Correira was used to measure the smartphone addiction of individuals (2). In the study by Yildırm and Correira, the reliability value (Cronbach Alpha) of the scale was found to be 0.95 , and the reliability value of its subscales were found to be $0.94 ; 0.87 ; 0.83$, and 0.81 (2). The Turkish version of this scale was developed by Yildirim, Sumuer, Adnan, and Yildirim $(2,10)$. In the study, the reliability value (Cronbach Alpha) of the scale was found to be 0.92 , and the reliability value of its sub-scales were found to be $0.90 ; 0.74 ; 0.94$, and 0.91 . These studies were completed on an adult group, mostly adolescents. Scale items were rated with 7-point Likert (1. Strongly Disagree, 7. Strongly Agree). The minimum score that can be obtained from the scale is 20 and the maximum is 140 , and the scores obtained are evaluated with the help of a scale. Accordingly, the 21-60 point range indicates mild nomophobia, the 61-100 point range moderate nomophobia, and the 101-140 point range indicates severe nomophobia. The minimum score that can be obtained from the scale is 20 and the maximum score is 140. Higher scores indicate higher levels of nomophobia $(2,10,11)$.

\section{Smartphone Addiction Scale-Short Form (SAS-SF)}

SAS-SF was developed by Kwon et al. to measure the risk of smartphone addiction in adolescents (12), and the Turkish validity and reliability study was conducted by Noyan et al. It is a scale evaluated with Likert grading. Scale items were scored from 1 to 6 . The range of the scale scores was between 10 and 60 , and higher scores indicated a higher risk for addiction. The scale has one factor and has no subscales. In the Korean sample, the cut-off score was determined as 31 for males and 33 for females. These studies were completed on the adult group. The Cronbach alpha coefficient of the original form's internal consistency and concurrent validity is 0.91 (12). The Cronbach alpha coefficient of the Turkish form was determined as 0.867 (3).

\section{Statistical Analysis}

Data were analyzed with IBM SPSS V23. Conformity to normal distribution was examined with the Kolmogorov-Smirnov test. Independent samples t-test was used to compare normally distributed scores according to gender. Paired samples t-test was used to compare normally distributed scores before and after the pandemic. Pearson correlation coefficient was used to examine the relationship between normally distributed scores. McNemar-Browker test was used to compare the nomophobia levels before and after the pandemic. Analysis results were presented as mean \pm standard deviation and median (minimummaximum) for quantitative data and as frequency (percentage) for categorical data. The significance level was accepted as $p<.05$. 


\section{Results}

Of the participants, $53 \%$ were female and $47 \%$ were male. The average age of the participants was 22.3 , the minimum age was 18.0 and the maximum age was 26.0. The participation rate of the university departments was found to be similar: $8 \%$ of the participants were students of the Faculty of Dentistry, Faculty of Education, Faculty of Science, Faculty of Communication, Faculty of Engineering, Faculty of Sport Sciences, and Faculty of Medicine; $7 \%$ of the participants were students of the Faculty of Health Sciences; $6 \%$ of the participants were students of the Faculty of Nursing and Faculty of Literature; $5 \%$ of the participants were students of the Faculty of Pharmacy, Department of Physiotherapy and Rehabilitation, Faculty of Fine Arts, Faculty of Law and Faculty of Economics and Administrative Sciences, respectively. The similar percentages of the participants from different education departments made our study more valid. While 39\% of the participants had mild nomophobia levels before the pandemic, 37\% had mild nomophobia levels after the pandemic (Table 1).

Table 1. Descriptive statistics for demographic characteristics

\begin{tabular}{|c|c|c|}
\hline & Frequency (n) & Percentage (\%) \\
\hline \multicolumn{3}{|l|}{ Gender } \\
\hline Female & 53 & 53 \\
\hline Male & 47 & 47 \\
\hline \multicolumn{3}{|l|}{ University Department } \\
\hline Faculty of Dentistry & 8 & 8 \\
\hline Faculty of Education & 8 & 8 \\
\hline Faculty of Science & 8 & 8 \\
\hline Faculty of Communication & 8 & 8 \\
\hline Faculty of Engineering & 8 & 8 \\
\hline Faculty of Sport Sciences & 8 & 8 \\
\hline Faculty of Medicine & 8 & 8 \\
\hline Faculty of Health Sciences & 7 & 7 \\
\hline Faculty of Literature & 6 & 6 \\
\hline Faculty of Nursing & 6 & 6 \\
\hline Faculty of Pharmacy & 5 & 5 \\
\hline Department of Physiotherapy and Rehabilitation & 5 & 5 \\
\hline Faculty of Fine Arts & 5 & 5 \\
\hline Faculty of Law & 5 & 5 \\
\hline Faculty of Economics and Administrative Sciences & 5 & 5 \\
\hline \multicolumn{3}{|l|}{ Nomophobia level before the pandemic } \\
\hline Mild & 39 & 39 \\
\hline Moderate & 32 & 32 \\
\hline Severe & 29 & 29 \\
\hline \multicolumn{3}{|l|}{ Nomophobia level after the pandemic } \\
\hline Mild & 37 & 37 \\
\hline Moderate & 32 & 32 \\
\hline Severe & 31 & 31 \\
\hline
\end{tabular}

A comparison was made to investigate the difference in the level of nomophobia before and after the pandemic and therefore its relationship with COVID-19 restrictions. There was no statistically significant difference between the distribution of nomophobia levels before and after the pandemic $(p=.135)$ (Table 2). 
Table 2. Comparison of pre- and post-pandemic nomophobia levels

\begin{tabular}{|l|c|c|c|c|}
\hline Nomophobia level before the pandemic & \multicolumn{3}{|c|}{ Nomophobia level after the pandemic } & \multicolumn{1}{c|}{ p* $^{*}$} \\
\hline Mild & Mild & Moderate & Severe & \\
\hline Moderate & $37(100)$ & $2(6.3)$ & $0(0)$ & .135 \\
\hline Severe & $0(0)$ & $30(93.8)$ & $2(6.5)$ & \\
\hline
\end{tabular}

*McNemar-Browker test

There was a statistically significant difference between the pre- and post-pandemic nomophobia scores of the participants $(p<.001)$. While the mean score before the pandemic was 74.2 , the mean score after the pandemic increased to 76.2. There was a statistically significant difference between the smartphone addiction scale scores of the participants before and after the pandemic $(p<.001)$. While the mean score before the pandemic was 34.0, it increased to 36.7 after the pandemic (Table 3).

Table 3. Comparison of pre- and post-pandemic scores and age information

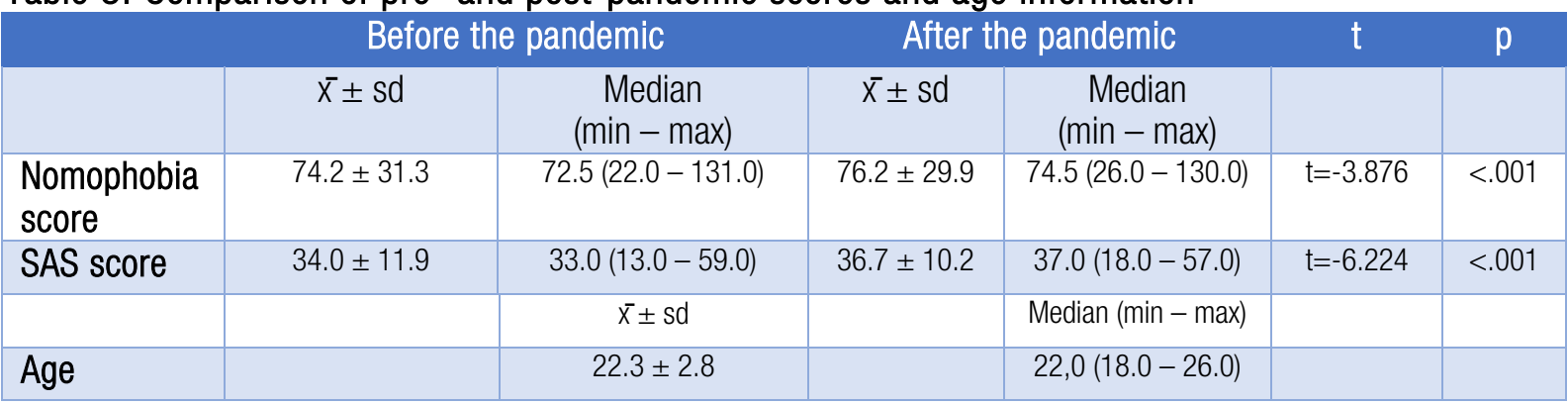

t: Paired samples t test statistic, $\bar{x}$ : mean, sd: standard deviation

To evaluate the impact of COVID-19 restrictions, the relationship between smartphone addiction and nomophobia should also be evaluated in terms of the association of addictions. There was no statistically significant relationship between the smartphone addiction scale score before and after the pandemic and the nomophobia score before the pandemic ( $p=.6530, p=.235$, respectively) (Table 4 ).

Table 4. Examination of the relationship between the scores

\begin{tabular}{|l|l|l|}
\hline Time & \multicolumn{2}{l}{ Nomophobia score before the pandemic } \\
\hline SAS score before the pandemic & $r$ & $p$ \\
\hline SAS score after the pandemic & .045 & .653 \\
\hline
\end{tabular}

r: Pearson correlation coefficient

Table 5. Comparison of scores by gender

\begin{tabular}{|c|c|c|c|c|c|c|}
\hline & Male & & Female & & $\mathrm{t}$ & $p$ \\
\hline & $\bar{x} \pm s d$ & $\begin{array}{l}\text { Median } \\
(\min -\max )\end{array}$ & $\bar{x} \pm s d$ & $\begin{array}{l}\text { Median } \\
(\min -\max )\end{array}$ & & \\
\hline $\begin{array}{l}\text { Nomophobia score before the } \\
\text { pandemic }\end{array}$ & $72.51 \pm 30.28$ & $72(23-124)$ & $75.75 \pm 32.40$ & $73(22-131)$ & $t=-515$ & .608 \\
\hline $\begin{array}{l}\text { Nomophobia score after the } \\
\text { pandemic }\end{array}$ & $74.64 \pm 29.48$ & $70(26-126)$ & $77.58 \pm 30.56$ & $76(28-130)$ & $t=-489$ & .626 \\
\hline Test statistic ${ }^{*}$ & $t=-3.391$ & & $t=-2.328$ & & & \\
\hline$p$ & .001 & & .024 & & & \\
\hline $\begin{array}{l}\text { SAS score before the } \\
\text { pandemic }\end{array}$ & $35.02 \pm 11.99$ & $35(13-59)$ & $33.11 \pm 11.92$ & $32(14-56)$ & $\mathrm{t}=.796$ & .428 \\
\hline SAS score after the pandemic & $37.32 \pm 10.33$ & $39(18-55)$ & $36.17 \pm 10.19$ & $36(18-57)$ & $\mathrm{t}=.559$ & .577 \\
\hline Test statistic* & $t=-3.590$ & & $t=-5.171$ & & & \\
\hline$p$ & .001 & & $<.001$ & & & \\
\hline
\end{tabular}

t: Independent samples t-test statistic, ${ }^{*}$ : Paired samples t-test statistic, $\bar{x}$ : mean, sd: standard deviation 
There was no relationship between scale scores and age or university department. There was also no difference between the scores of nomophobia and smartphone addiction before and after the pandemic concerning gender. There was a difference in Nomophobia scores before and after the pandemic in men $(p=.001)$. While the mean score before the pandemic was 72.51 , it increased to 74.64 after the pandemic. There was a difference between Nomophobia scores before and after the pandemic in women $(p=.024)$. While the mean score before the pandemic was 75.75 , it increased to 77.58 after the pandemic. There was a difference between smartphone addiction scale scores before and after the pandemic in men $(p=.001)$. While the mean score before the pandemic was 35.02 , the mean score after the pandemic increased to 37.32. There was a difference between smartphone addiction scale scores before and after the pandemic in women $(p<.001)$. While the mean score before the pandemic was 33.11, it increased to 36.17 after the pandemic (Table 5).

\section{Discussion}

Since the need for technology has come to the forefront after the COVID-19 pandemic restrictions, an increase in addiction levels was observed. A significant increase was found in both nomophobia and smartphone addiction in the present study. Although no difference was found between genders, the significant increase in nomophobia and smartphone addiction was found within the genders. There are also studies showing that undergraduate students' emotions of anger have increased significantly due to the uncertainty during the COVID-19 pandemic period, in addition to nomophobia and mobile phone addiction (13).

In China, where the COVID-19 Pandemic was first seen, a significant relationship was found between problematic smartphone use level and COVID-19 anxiety symptoms in adults (14). Similar to the findings of the present study, it was stated that problematic smartphone use increased due to the increase in addiction levels and this increase was the cause of anxiety.

In a study conducted on medical students in Malaysia during the COVID-19 pandemic, it was stated that the level of smartphone addiction increased, and the participants even used a smartphone or an additional device in the first 15 minutes after waking up (15). In our country (Turkey) in the other studies conducted on students' pandemic period of excessive use of smartphones (score 88.4), and that has been reported to correlate well with increased levels of nomophobia (16). In the present study, only the changes in smartphone usage levels during the pandemic were examined, and a significant increase was observed in smartphone addiction levels following this study.

Studies have reported an increase of approximately $70 \%$ in internet traffic related to online games due to pandemic restrictions (16). In another study conducted in China, it was reported that $46.8 \%$ of the participants increased internet addiction during the COVID-19 pandemic. The prevalence of severe internet addiction increased from 3.5\% to $4.3 \%$ compared to before the COVID-19 pandemic, increasing by $23 \%$ $(16,17)$.

It has been shown by Lin et al. that the genders can be compared with the nomophobia scale (19). Many studies have examined the relationship between smartphone addiction levels and gender. Although this level is high in men, studies are indicating that the level of addiction is higher in women in cases of negative mood such as depression and anxiety (20). In the present study, no relationship was found between gender and both nomophobia nor smartphone addiction levels, and an increase was observed in nomophobia and smartphone addiction levels after the pandemic for both genders.

According to the results of the research conducted during the pandemic period; it was stated that the students were ready for online learning but found themselves insufficient in terms of online learning control. It has been determined that online learning readiness differs according to the undergraduate students' classes and their previous online learning experience $(21,22)$. The increase in nomophobia levels should not be strange, since the pandemic has passed 1 year and therefore online education cannot be given up. 
The present study is important in terms of evaluating addiction types related to technology, which has become one of the crucial needs in situations that may cause behavioral changes such as pandemics. We think that the reliability of the study is high as the addiction levels of the same individuals were compared over different time points. By drawing attention to the high frequency of nomophobia and smartphone addiction in young adults, which are also mentioned in the study results, we believe that this study will be a guide for further studies on this subject.

The limitations of the present study were the small sample size due to the pandemic and the fact that it was conducted only in a single university sample. In this sense, prospective studies with a larger sample can make a significant contribution to the field.

As all nations were caught unprepared for the COVID-19 pandemic and the future is still full of uncertainties, changes in human psychology and lifestyle are inevitable. Due to the restrictions related to the pandemic, the need for technology, especially smartphones and computers, which are the most popular smart devices, has become a necessity causing addiction and also increasing existing addiction levels. Types of addiction are interrelated with each other and are directly related to mood; therefore, they affect each other. In these cases, treatments become difficult. To control the increase in smartphone addiction and nomophobia levels, it may even be necessary to issue certain regulations as part of pandemic restrictions. It may be necessary to take concrete and rational measures such as limiting online education, preparing public spots on visual and social media in terms of the usage time of smartphones and all internet devices, and informing the adolescent age group on technology usage with the cooperation of teachers and psychologists. Regular and adequate sleep, regular and healthy food, adequate fluid intake, and attention to personal hygiene can not only protect physical health, but also psychological wellbeing, which is necessary for health in the pandemic.

\section{Kaynaklar}

1. King ALS, Valença AM, Silva ACO, et al. Nomophobia: Dependency on virtual environments or social phobia? Comput Human Behav 2013; 29: 140-144.

2. Yildirim C, Correia AP. Exploring the dimensions of nomophobia: Development and validation of a self-reported questionnaire. Comput Human Behav 2015; 49: 130-137.

3. Noyan CO, Enez Darçın A, Nurmedov S, et al. 0, Dilbaz N. Validity and reliability of the Turkish version of the Smartphone Addiction Scale-Short Version among university students. Anadolu Psikiyatri Derg 2015; 16: 7183.

4. Cook DA, Beckman TJ. Current concepts in validity and reliability for psychometric instruments: Theory and application. Am J Med 2006; 119(2): 166.e7-16.

5. Polat R. Nomophobia as digital disease. e-Journal of New Media 2017; 1(2): 164-172.

6. Savci M, Aysan F. Technological addictions and social connectedness: predictor effect of internet addiction, social media addiction, digital game addiction and smartphone addiction on social connectedness. Dusunen Adam 2017; 30(3): 202-216.

7. Mail Online. (2008). "Nomophobia is the fear of being out of mobile phone contact - and it's the plague of our 24/7 age". Available from: URL:http://www.dailymail.co.uk/ news/article550610/ Nomophobia-fear-mobilephonecontact-plague-24-7-age.html. Accessed date: 24.04.2021.

8. Murthy P. How will Covid-19 influence addictive behaviours and their management? J Psychosoc Rehabil Ment Health 2020; 7: 203-205.

9. Eidi A, Delam H. Internet addiction is likely to increase in home quarantine caused by coronavirus disease 2019 (COVID 19). Journal of Health Sciences Surveillance System; 2020; 8(3): 142-143.

10. Yildirim C, Sumuer E, Adnan M, Yildirim S. A growing fear: Prevalence of nomophobia among Turkish college students. Information Development 2015; 32(5): 1322-1331.

11. Türen U, Erdem H, Kalkın G. No mobile phone phobia (Nomophobia) prevalence: samples of undergraduate students and public employees from Turkey. Journal of Information Technologies 2017;10(1):1-12.

12. Kwon M, Kim DJ, Cho H, Yang S. The smart phone addiction scale: development and validation of a short version for adolescents. PloS One 2013; 8: e83558. 
13. Kumar AR, Thomas S. Study on nomophobia and anger among undergraduates during covid-19 pandemic. International Journal of Indian Psychology 2020; 8(3): 1397-1403.

14. Elhai JD, Yang H, McKay D, Asmundson GJG (2020) COVID-19 anxiety symptoms associated with problematic smartphone use severity in Chinese adults. J Affect Disord 2020; 274: 576-582.

15. Kamaruddin PSNM, Nawi AM. Smartphone usage and pattern on self-reported symptoms among medical students in Universiti Kebangsaan Malaysia during the COVID-19 lockdown. 01 September 2020, PREPRINT (Version 1) Research Square; doi:10.21203/rs.3.rs-67820/v1 .

16. Atilgan S. Determining the nomophobia level among the university students using smartphones. Electronic Journal of Cumhuriyet Communication 2020; 2(2): 6-23.

17. Gökler M, Turan Ş. Problematic technology use in The Covid-19 pandemic. ESTUDAM Public Health Journal. 2020; 5: 108-114.

18. Sun Y, Li Y, Bao Y, et al. Brief Report: increased addictive internet and substance use behavior during the COVID 19 pandemic in China. Am J Addict 2020; 29(4): 268-270.

19. Lin CY, Griffiths MD, Pakpour AH. Psychometric evaluation of Persian Nomophobia Questionnaire: Differential item functioning and measurement invariance across gender. J Behav Addict 2018; 7(1):100-108.

20. Chen B, Liu F, Ding S, et al. Gender differences in factors associated with smartphone addiction: a crosssectional study among medical college students. BMC Psychiatry 2017; 17: 341.

21. Kumar AR, Thomas S. Study on nomophobia and anger among undergraduates during covid-19 pandemic. International Journal of Indian Psychology 2020; 8(3): 1397-1403.

22. Sarıtaş E, Barutçu S. Digital transformation in education and students' readiness to learn online: A research on Pamukkale University students in the period of pandemic. Journal of Internet Applications and Management 2020; 11(1): 5-22. 